\title{
Arbuscular mycorrhizae on Tetraclinis articulata (Cupressaceae): development of mycorrhizal colonization and effect of fertilization and inoculation
}

\author{
G Díaz, M Honrubia \\ Departamento de Biologia Vegetal (Botánica), Facultad de Biologia, Campus de Espinardo, E30071 Murcia, Spain
}

(Received 15 July 1992; accepted 9 February 1993)

\begin{abstract}
Summary - Seedlings of Tetraclinis articulata (Vahl) Masters (Cupressaceae) growing under nursery conditions were surveyed for mycorrhizal colonization over a period of time. They showed a typical vesicular-arbuscular mycorrhizal colonization, with percentages of infection ranging between $0 \%$ (1-month-old seedlings) to $72 \%$ (17-month-old seedlings), and a 3-phase pattern of mycorrhizal development. In addition, growth responses of $T$ articulata in sterile soil were observed by inoculation with several mycorrhizal fungi: Glomus mosseae was the most effective in improving growth, and $G$ fasciculatum was the most ineffective. This fungus was also tested at different levels of added $P$ : maximum yield was obtained in mycorrhized plants at $60 \mathrm{mg} \mathrm{kg}^{-1} \mathrm{P}$ level and no significant differences between mycorrhized and control plants were found at high fertilization rates.
\end{abstract}

endomycorrhiza / P fertilization / inoculation / Tetraclinis articulata / colonization development

Résumé - Mycorhizes arbusculaires sur Tetraclinis articulata (Cupressaceae): développement de colonisation mycorhizienne et effet de la fertilisation et de l'inoculation. L'étude de la mycorhization de plantules de Tetraclinis articulata (Vahl) Masters (Cupressaceae) dans des conditions de pépinière a été menée sur une période de 3 ans. Une colonisation typique avec des mycorhizes à vésicules et arbuscules a été developpée dans des pourcentages compris entre $0 \%$ (pour plantules de 1 mois) et 72\% (pour plantules de 17 mois), avec un modèle de développement mycorhizien à 3 phases. Des réponses de croissance de $T$ articulata sur sol stérile ont été mises en évidence, après des inoculations avec différents champignons mycorhiziens. Glomus mosseae a montré la meilleure efficacité dans la stimulation de croissance de $\mathrm{T}$ articulata, tandis que $\mathrm{G}$ fasciculatum s'est révélé le plus infectieux. On a étudié aussi ce dernier, par rapport à différents niveaux d'apport de $P$ : la récolte maximale a été obtenue sur des plantes mycorhizées, avec un apport de $60 \mathrm{mg} \cdot \mathrm{kg}^{-1}$ de $P$. On n'a pas trouvé de différences significatives au niveau de la croissance par rapport aux fortes doses de fertilisants.

\section{INTRODUCTION}

Tetraclinis articulata (Vahl) Masters is a member of the Cupressaceae of North African origin. In Europe it is only reported in Malta and in the Southern Iberian Peninsula (Sierra de Cartagena) (Guerra et al, 1988). $T$ articulata has been used in nurseries in southeastern Spain for use in revegetation programmes. Many commercially important woody species form arbuscular mycorrhizae (AM). The contribution of mycorrhizae to plant growth, uptake of immobile nutrients, reduction of transplant mortality etc, are well known (Harley and Smith, 1983) and could also be important in seedling development and production of this species in nurseries.
The presence of AM in gymnosperms ( $\mathrm{Cu}$ pressaceae and Taxodiaceae) has been reported previously (Malloch and Malloch, 1982; Klopatek et al, 1988; Castellano and Molina, 1989; Brundrett et al, 1990). Several papers also report growth responses in these species induced by AM (Maronek et al, 1980; Bartschi et al, 1981; Parke et al, 1983; Kough et al, 1985).

The objectives of our study were first to determine the mycorrhizal status of $T$ articulata seedlings and investigate root colonization development over time; and secondly, to study $T$ anticulata growth response to $A M$ inoculation and $\mathrm{P}$ fertilization. 


\section{MATERIALS AND METHODS}

\section{Assessment of mycorrhizal status}

Plants growing in unsterilized soils under nursery conditions were surveyed for the presence of AM natural colonization. Ten randomly selected seedlings were examined $\approx$ every 2 months from $30 \mathrm{~d}$ after sowing to $3 \mathrm{yr}$ of age. Plant height was recorded, and shoot and root weights determined after drying $\left(80^{\circ} \mathrm{C}\right.$ for $\left.16 \mathrm{~h}\right)$. AM colonization was assessed on cleared and stained root samples (Phillips and Hayman, 1970). The roots of $T$ articulata are thick and intensely pigmented so they were heated in $10 \% \mathrm{KOH}$ at $90{ }^{\circ} \mathrm{C}$ for $210 \mathrm{~min}$ and later immersed in 10 vol hydrogen peroxide at $40^{\circ} \mathrm{C}$ for $30 \mathrm{~min}$. The percentage of $\mathrm{AM}$ root colonization was estimated according to the gridline intersect method (Giovannetti and Mosse, 1980) under a stereoscopic microscope (magnification $\times 40$ ). The presence of internal hyphae, vesicles and/or arbuscules was recorded from each mycorrhizal intersect under 100x and 400x magnifications and expressed as a percentage to determine the stage of AM infection in relation to plant age. Three categories were established according to the morphological features of colonization: percentage of mycorrhizal root length containing vesicles (this includes the intersects with vesicles alone or vesicles and arbuscules), percentage of mycorrhizal root length containing only arbuscules, and percentage of mycorrhizal root length with only internal hyphae.

\section{Effect of $P$ fertilization and inoculation}

\section{Soil}

The soil used in the experiments had a pH of 7.6, 8.99 $\mathrm{mg} \mathrm{kg}^{-1}$ available $\mathrm{P}, 12.5 \mathrm{mg} / 100 \mathrm{~g}$ available $\mathrm{K}, 1.94$ $\mathrm{mg} / 100 \mathrm{~g}$ total $\mathrm{N}, 1.14 \%$ organic matter and $5.92 \%$ $\mathrm{CaCO}_{3}, 26.5 \%$ sand, $49.7 \%$ silt and $23.8 \%$ clay. Soil was sieved through a $4-\mathrm{mm}$ mesh sieve, sterilized for 60 min at $100^{\circ} \mathrm{C}$ on 3 consecutive days and placed in $17.5 \times 10-\mathrm{cm}$ plastic bags commonly used in nursery practice in southern Spain. Ten replicates per treatment were prepared.

\section{Plants}

$T$ articulata seeds were provided by EI Valle tree nursery and maintained at $4{ }^{\circ} \mathrm{C}$ until use. Seeds were germinated in the bags and seedlings were thinned to 2 per bag after $30 \mathrm{~d}$.

\section{Inoculation}

Four AM fungi were propagated on alfalfa pot cultures for at least 1 yr. Glomus etunicatum Becker et Gerde- mann, Glomus mosseae Nicolson et Gerdemann, and Glomus sp GPR31 were isolated from the rhizosphere of Medicago sativa L growing in a sandy soil in Portman (Murcia, Spain); Glomus fasciculatum (Thaxter sensu Gerdemann) Gerdemann and Trappe was provided by the Zaidin Experimental Station (Granada, Spain). Each replicate received $10 \mathrm{~g}$ inoculum consisting of soil, mycorrhizal root fragments and spores from the pot cultures. The inoculum was placed at a depth of $5 \mathrm{~cm}$ and gently mixed with the soil.

\section{Experimental design}

Two separate experiments were carried out. In the first experiment, the effect of $P$ fertilization was studied in uninoculated plants or plants inoculated with $G$ fasciculatum. Five levels were obtained by adding $\mathrm{PO}_{4} \mathrm{H}_{2} \mathrm{~K}$ in solution at the rates of $0,30,60,120$ and $240 \mathrm{mg}$ $\mathrm{kg}^{-1}$ soil. In the second experiment, the effects of the 4 above-mentioned AM fungi were tested and compared with nonmycorrhizal control plants, in order to check mycorrhizal efficiency. The plants were grown in the greenhouse under natural light/dark conditions and watered when needed.

\section{Plant analysis}

Plants were harvested 6 months after sowing. Plant height and dry weight $\left(80^{\circ} \mathrm{C} 16 \mathrm{~h}\right)$ of shoot and roots were recorded. The root systems were randomly subsampled and stained as previously described for assessment of mycorrhizal colonization, and percentage of colonization estimated. All the shoots in a treatment were mixed. Five hundred $\mathrm{mg}$ of leaf tissue from each bulked sample were digested in nitric-perchloric acid $5: 3$ for $2 \mathrm{~h}$ at $130^{\circ} \mathrm{C}$ and $4-6 \mathrm{~h}$ at $204^{\circ} \mathrm{C}$. P concentration was estimated colorimetrically with malachite green reagent (Fernandez et al, 1985) in Uvikon 930 spectrophotometer at $660 \mathrm{~nm}$ wavelength. Data were subjected to analysis of variance (ANOVA test). Interactions between inoculation and fertilization were established in the first experiment. Mean separation in the second experiment was performed using Duncan's multiple range test (Duncan, 1955) after a significant $F$-test.

\section{RESULTS}

\section{Assessment of mycorrhizal status}

The root system of $T$ articulata showed typical AM colonization. Under the experimental conditions described, the roots began to be colonized by natural endophytes between 1 and 2 months after sowing. After that time, infection was 
present in all the sampled seedlings (fig 1) with percentages of colonization increasing gradually from $20 \%$ to $50 \%$ in 2 - and 7 -month old seedlings respectively. Then the infection remained stable. Older seedlings showed percentages of colonization ranging from $44-72 \%$ with several variations. Data on plant growth are presented in figure 2. On the other hand, qualitative changes in colonization with time were observed. The morphological features of colonization in relation to plant age are shown in figure 3 . The infection was exclusively of the arbuscular type in plants up to 5 months old. After that time, the percentage of roots exclusively colonized by arbuscules decreased at the same time as the percentage of roots containing vesicles (that is, vesicles and arbuscules or vesicles alone) increased. In 2-yr-old plants, no roots containing only arbuscules were recorded, but they were always recorded together with vesicles.

\section{Effect of P fertilization}

The results of fertilization on $T$ articulata are shown in figure 4. The biomass of $T$ articulata was increased by $P$ fertilization and mycorrhizal inoculation (fig $4 A, B, C$ ). Inoculated plants were taller and had greater dry weights than the nonmycorrhized controls at low and intermediate $P$ levels; so the beneficial effects of AM compared to controls in terms of plant growth were observed up to $60 \mathrm{mg} \mathrm{kg}^{-1}$ of applied phosphorus. Maximum yield was obtained in mycorrhized plants at $60 \mathrm{mg} \mathrm{kg}^{-1} \mathrm{P}$ level. Higher doses of $\mathrm{P}$ addition produced a growth depression in mycorrhized plants, but not in $\mathrm{P}$ content. Thus, at 240

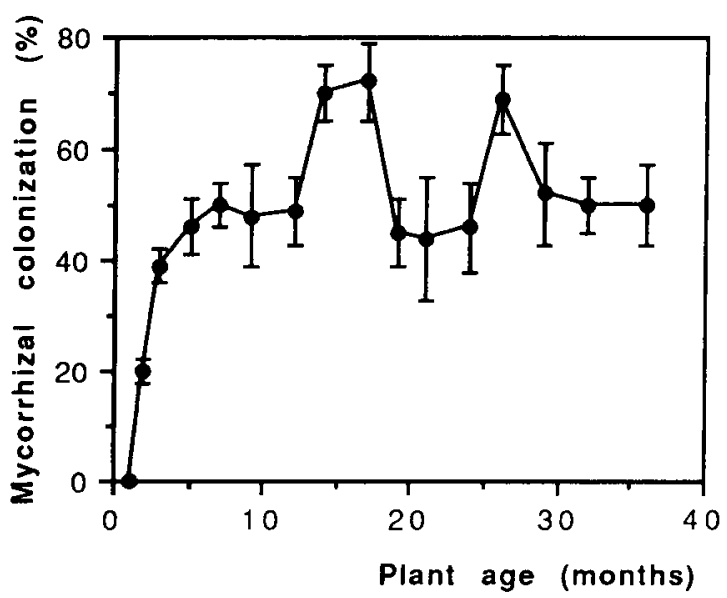

Fig 1. Mycorrhizal colonization of the roots of Tetraclinis articulata in relation to plant age. Symbols represent means of 10 replicates. Bars represent SD. $\mathrm{mg} \mathrm{kg}{ }^{-1} \mathrm{P}$ level there was no significant difference in the shoot dry weight between inoculated and control plants. No significant differences in root dry weight were found in response to mycorrhizal inoculation or $\mathrm{P}$ fertilization, suggesting that these treatments only affected shoot biomass (table I). Microscopic examination of stained root segments revealed mycorrhizal colonization in all cases, but an increase in added $P$ resulted in a decreased percentage of colonization (fig 4E). Mycorrhizal inoculation increased $P$ concentration in tissue at all levels of added $P$ (fig 4D). However, for each inoculation treatment, $\mathrm{P}$ concentration in shoots varied little at different fertilizer levels. When $240 \mathrm{mg} \mathrm{kg}^{-1} \mathrm{P}$ was applied, a slightly decreased $P$ concentration was found in mycorrhized plants.

\section{Effect of inoculation with several endophytes}

The effects of inoculation on plant growth, mycorrhizal colonization and $\mathrm{P}$ concentration in $T$ articulata are shown in table II. Plants inoculat-
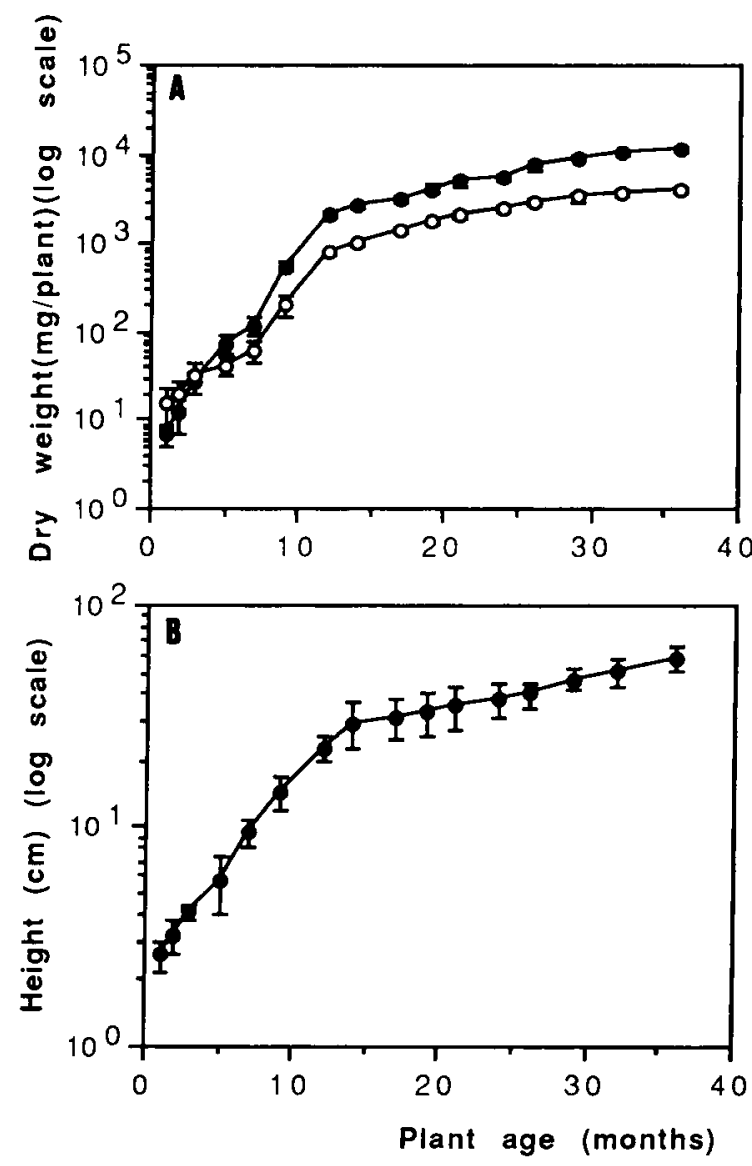

Fig 2. Plant growth expressed as log dry weight of shoot (@) and root $(O)(A)$ and log height $(B)$ in relation to plant age. Symbols represent means of 10 replicates. Bars represent SD. 
Table I. Results of analysis of variance of height, shoot and root dry weight and mycorrhizal colonization as influenced by $P$ fertilization and inoculation with Glomus fasciculatum.

\begin{tabular}{|c|c|c|c|c|c|}
\hline Source of variation & $D F$ & Sum of squares & Mean squares & $\mathrm{F}$ & $P$ \\
\hline \multicolumn{6}{|l|}{ Height } \\
\hline Inoculation & 1 & 79.736 & 79.736 & 39.93 & 0.0000 \\
\hline Fertilization & 4 & 37.019 & 9.254 & 4.63 & 0.0021 \\
\hline Inoculation $x$ fertilization & 4 & 50.108 & 12.527 & 6.27 & 0.0002 \\
\hline Residual & 83 & 165.750 & 1.997 & & \\
\hline Total & 92 & 332.620 & & & \\
\hline \multicolumn{6}{|l|}{ Shoot dry weight } \\
\hline Inoculation & 1 & $1.525 \times 10^{5}$ & $1.525 \times 10^{5}$ & 29.41 & 0.000 \\
\hline Fertilization & 4 & $3.022 \times 10^{4}$ & 7555.4 & 1.46 & 0.2217 \\
\hline Inoculation $x$ fertilization & 4 & $6.653 \times 10^{4}$ & $1.663 \times 10^{4}$ & 3.21 & 0.0168 \\
\hline Residual & 83 & $4.304 \times 10^{5}$ & 5185.7 & & \\
\hline Total & 92 & $6.797 \times 10^{5}$ & & & \\
\hline \multicolumn{6}{|l|}{ Root dry weight } \\
\hline Inoculation & 1 & 6789.2 & 6789.2 & 1.70 & 0.1961 \\
\hline Fertilization & 4 & $1.313 \times 10^{4}$ & 3282.9 & 0.82 & 0.5174 \\
\hline Inoculation $\times$ fertilization & 4 & $1.224 \times 10^{4}$ & 3060.7 & 0.77 & 0.5530 \\
\hline Residual & 83 & $3.317 \times 10^{5}$ & 3997.5 & & \\
\hline Total & 92 & $3.639 \times 10^{5}$ & & & \\
\hline \multicolumn{6}{|l|}{ Mycorrhizal colonization } \\
\hline Regression & 1 & 3516.30 & 3516.3 & 176.10 & 0.0000 \\
\hline Residual & 29 & 579.07 & 19.968 & & \\
\hline Total & 30 & 4095.40 & & & \\
\hline
\end{tabular}

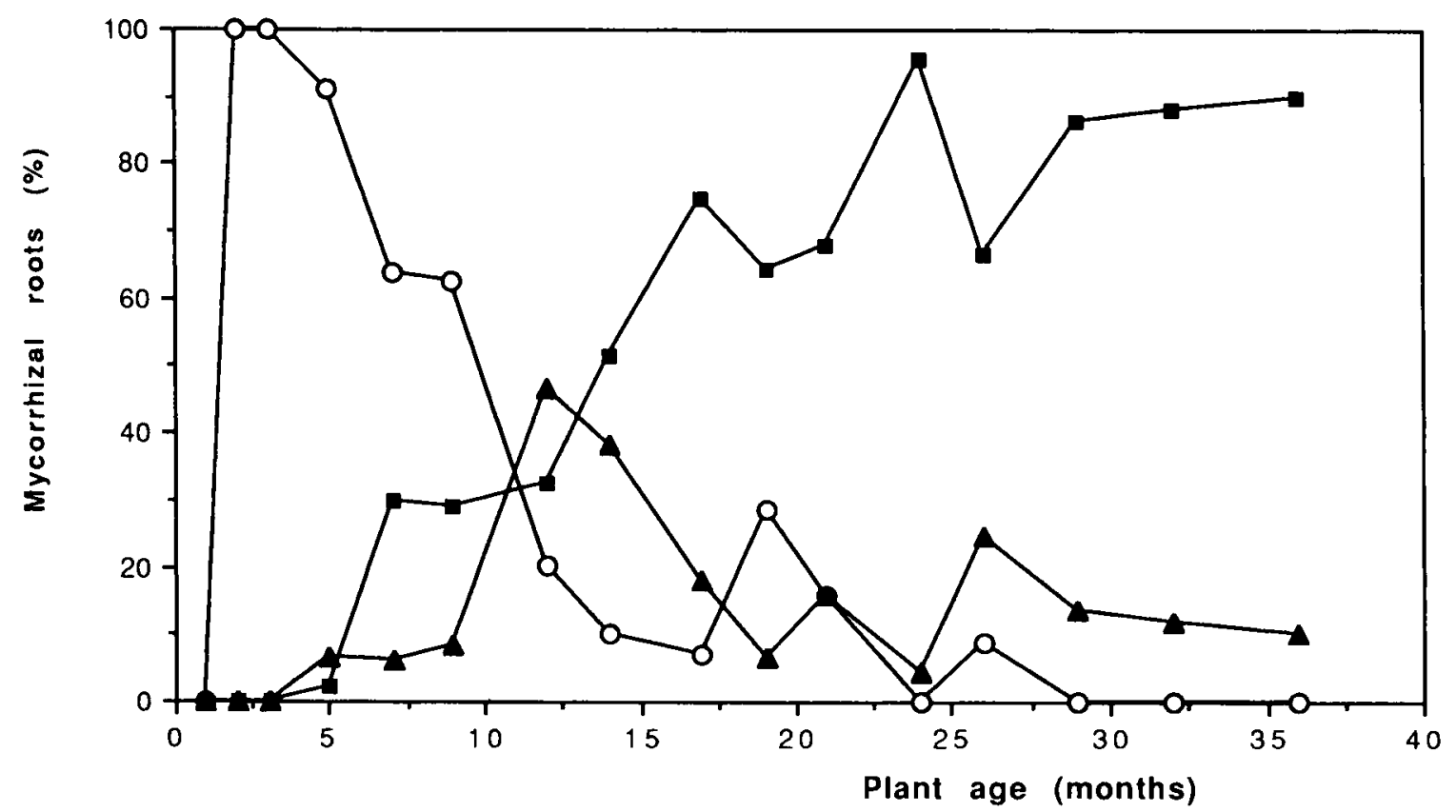

Fig 3. Morphological features of mycorrhizal colonization in relation to the plant age. Lines represent the percentage of mycorrhizal roots containing vesicles or vesicles and arbuscules $(\square)$, only arbuscules $(O)$, or only internal hyphae $(\mathbf{A})$. 
Table II. Effect of inoculation with several AM fungi on plant growth and mycorrhizal colonization of Tetraclinis articulata.

\begin{tabular}{|c|c|c|c|c|c|}
\hline \multirow[t]{2}{*}{ Treatment } & \multirow{2}{*}{$\begin{array}{c}\text { Height } \\
(\mathrm{cm})\end{array}$} & \multicolumn{2}{|c|}{ Dry weight (mg/plant) } & \multirow{2}{*}{$\begin{array}{c}\text { Shoot } P \text { concentration } \\
\left(m g \mathrm{~kg}^{-1}\right)\end{array}$} & \multirow{2}{*}{$\begin{array}{c}\text { Mycorrhizal } \\
\text { colonization (\%) }\end{array}$} \\
\hline & & Shoot & Root & & \\
\hline Control & $6.1 \pm 0.5^{a}$ & $94 \pm 23 a$ & $35 \pm 13 a$ & 312 & $0 \pm 0^{a}$ \\
\hline G fasciculatum & $8.4 \pm 0.5 b$ & $196 \pm 21 b c$ & $75 \pm 12^{b}$ & 912 & $32 \pm 3 c$ \\
\hline G mosseae & $10.7 \pm 0.7 c$ & $264 \pm 32 c$ & $112 \pm 17 b c$ & 1204 & $25 \pm 7 c$ \\
\hline G etunicatum & $8.5 \pm 0.4^{b}$ & $173 \pm 18 b$ & $117 \pm 10^{c}$ & 523 & $7 \pm 4 b$ \\
\hline Glomus sp GPR31 & $8.2 \pm 0.4 b$ & $210 \pm 17 b c$ & $93 \pm 9 b c$ & 1324 & $18 \pm 8 b c$ \\
\hline \multicolumn{6}{|l|}{$F$-values } \\
\hline Control $x$ inoculated & 7.70 & 5.95 & 8.04 & - & 44.02 \\
\hline Inoculated & 3.35 & 1.89 & 3.63 & - & 27.63 \\
\hline
\end{tabular}

Data expressed as mean of 10 replicates \pm SE. Values followed by the same letter in a column are not significantly different $(P \leq$ $0.05)$, as determined by Duncan's test. $F$-values from $F$-test for significance of data.

ed with all the Glomus species used in the experiment were significantly $(P \leq 0.05)$ greater in height and biomass than uninoculated plants. The effect of inoculation with $G$ mosseae on shoot dry weight was greater than with the other endophytes, whereas the least effective fungus for growth improvement was $G$ etunicatum. $G$ fasciculatum showed the highest percentage of root colonization $(32 \%)$ and $G$ etunicatum the lowest $(7 \%)$. Phosphorus concentration in shoots was clearly increased by colonization with $G$ mosseae and Glomus sp GPR31. The data on P concentration confirms the results obtained for dry weights, since $G$ etunicatum was also the least efficient endophyte for $P$ uptake.

\section{DISCUSSION}

In the present study, AM colonization in $T$ articulata seedlings growing in natural nursery soils has been reported, which confirms the mycorrhizal status of Cupressaceae plant species. There were 3 phases of mycorrhizal development (Sutton, 1973): a lag phase, a phase of extensive mycorrhizal development and a constancy phase. The lag phase lasted 1-2 months and covered the time necessary for root development, AM propagule activation and host penetration. The exponential development phase extended from 2 to 5-7 months. This stage, when the infection was predominantly of the arbuscular type, corresponded to a generalization of colonization, devel- opment of hyphae from the entrance points and the massive formation of arbuscules, as a site of plant-fungus metabolite interchange. After 5-7 months, infection seemed to stabilize and this constant phase, when there was a decrease in the percentage of roots exclusively colonized by arbuscules and an increase in the percentage of vesicles, corresponded to the formation of vesicles as a reserve structure for the fungus (Bonfante-Fasolo, 1984). This prior formation of arbuscules and the subsequent development of vesicles at a later stage is a characteristic of AM infection (Dodd and Jeffries, 1986; Douds and Chaney, 1986).

It is also of note that the percentages of colonization in these nursery conditions with unsterilized soil were higher than when AM fungi were used in sterilized soils. It is possible that a mixed infection caused by several fungi more effectively colonizes the root system than the isolated AM fungi used in our experiments. Moreover, soil sterilization could affect some edaphic characteristics or release certain nutrients, and this effect could alter the penetration mechanism and colonization of the root systems by the fungus, as Habte and Aziz (1985) hypothesized. Soil sterilization eliminates the microorganisms and therefore their possible effect on improving mycorrhizal establishment (Azcón-Aguilar and Barea, 1985). Another possibility is that a better edaphic adaptation of natural fungi present in soil could lead to faster and more efficient root colonization (Sainz and Arines, 1988). 

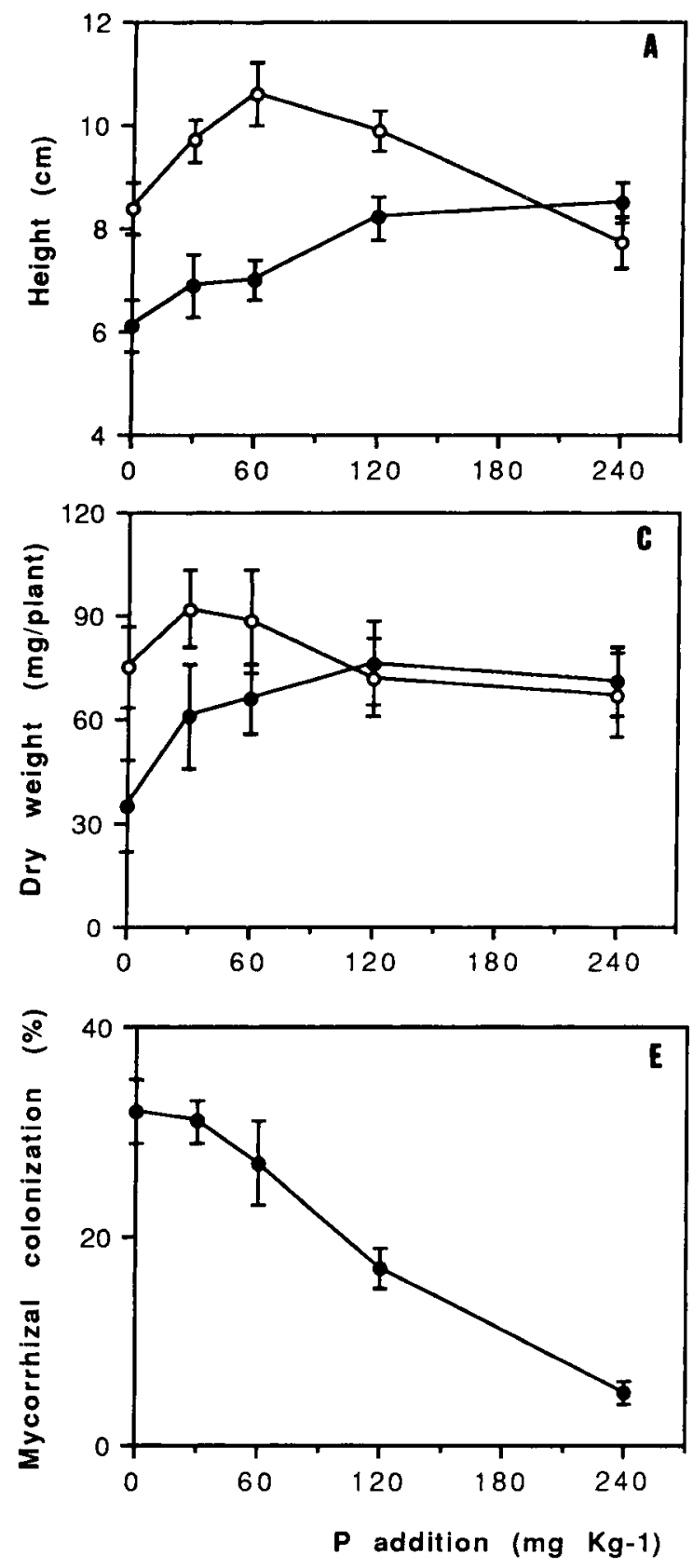

It has been shown in this work that AM were efficient in promoting plant growth of $T$ articulata seedlings, but this stimulation varied depending on the fertility level in the soil. The highest beneficial mycorrhizal effect was obtained at low $P$ levels, in accordance with reports on other plant species (Hayman, 1983; Smith and GianinazziPearson, 1988). $P$ fertilization also influenced endophyte development in the root, but mycorrhizal colonization was not totally eliminated even by the highest doses of $P$ fertilization used. The general pattern that colonization decreases with increasing fertilization (Thomson et al, 1986; Waterer and Coltman, 1988; Hetrick et al, 1990) could be related to the inhibitory effect of high $\mathrm{P}$
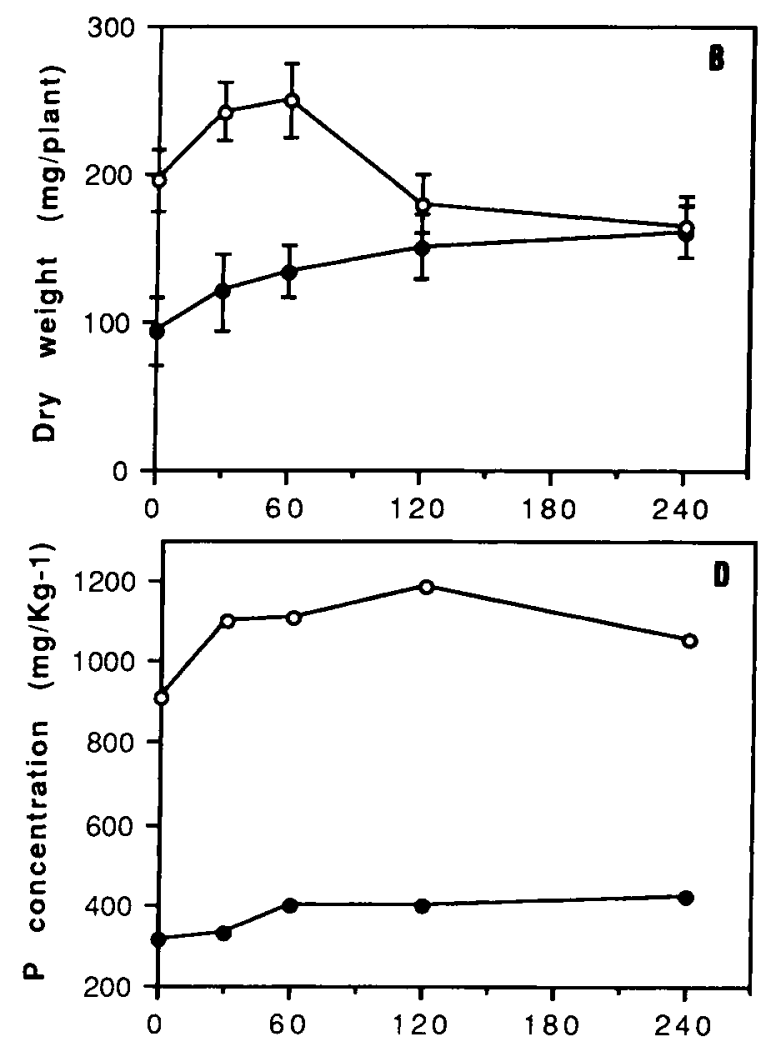

Fig 4. Effect of $P$ fertilization on height (A), shoot dry weight (B), root dry weight (C), shoot $P$ concentration (D) and mycorrhizal colonization (E) of plants of Tetraclinis articulata uninoculated (O) or inoculated with Glomus fasciculatum $(O)$.

content in the plant on mycorrhizal colonization (Cooper, 1984) or even to the nutritional status of roots (Koide and Li, 1990). The addition of $\mathrm{P}$ had little effect on plant growth of non-mycorrhized seedlings when compared with the effect obtained by mycorrhizal inoculation; thus, AM fungi inoculation seems to be essential for good growth of this plant.

Different $A M$ fungi isolates may confer very variable benefits on the same host plant (Barea, 1991). Under the experimental conditions described, 2 autochthonous strains, $G$ mosseae and Glomus sp GPR31 were the most efficient in promoting both plant growth and $\mathbf{P}$ uptake in $T$ articulata. Mycorrhizal colonization by the fungi 
used in our experiments was always $<32 \%$. This confirms data already reported (Hayman and Tavares, 1985; Aziz and Habte, 1990), where it was shown that even with low percentages of colonization, AM fungi could significantly improve plant growth.

The data presented here show that $T$ articulata could be considered a mycorrhiza-dependent species. Thus an adequate selection and manipulation of AM fungi seems to be decisive in increasing plant growth of this member of the Cupressaceae in nurseries.

\section{ACKNOWLEDGMENTS}

The authors wish to thank $C$ Azcón-Aguilar from Zaidín Experimental Station, Granada, Spain, for reviewing the manuscript. The research reported in this paper was supported in part by Agencia Regional del Medio Ambiente de la Región de Murcia, Spain.

\section{REFERENCES}

Azcón-Aguilar C, Barea JM (1985) Effect of soil microorganisms on formation of vesicular-arbuscular mycorrhizas. Trans Br Mycol Soc 84, 536-537

Aziz T, Habte M (1990) Enhancement of edomycorrhizal activity through nitrogen fertilization in cowpea grown in an oxisol subjected to simulated erosion. Arid Soil Res Rehabil 4, 131-139

Barea JM (1991) Vesicular-arbuscular mycorrhizae as modifiers of soil fertility. In: Advances in Soil Science (Stewart BA, ed) Springer-Verlag New York, vol 15, 1-40

Bartschi H, Gianinazzi-Pearson V, Vegh I (1981) Vesicular-arbuscular mycorrhiza formation and root rot disease (Phytopthora cinnamomi) development in Chamaecyparis lawsoniana. Phytopathol $Z 102$, 213-218

Bonfante-Fasolo $\mathrm{P}$ (1984) Anatomy and morphology of VA mycorrhizae. In: VA Mycorrhiza (Powell CL, Bagyaraj DJ, eds) CRC Press, Boca Raton, FL, 533

Brundrett M, Murase F, Kendrick B (1990) Comparative anatomy of roots and mycorrhiza of common Ontario trees. Can J Bot 68, 551-578

Castellano MA, Molina R (1989) Mycorrhizae. In: The Container Tree Nursery Manual Vol 5: The Biological Component: Nursery Pests and Mycorrhizae (Landis TD, Tinus RW, McDonald SE, Barnett JP, eds) USDA, For Serv, Washington DC, 101-117

Cooper DM (1984) Physiology of VA mycorrhizal associations. In: VA Mycorrhizae (Powell CL, Bagyaraj DJ, eds) CRC Press, Boca Raton, FL, 113-130
Dodd JC, Jeffries P (1986) Early development of vesicular-arbuscular mycorrhizas in autumn-sown cereals. Soil Biol Biochem 18, 149-154

Douds DPJr, Chaney WR (1986) The effect of high nutrient addition upon seasonal patterns of mycorrhizal development, host growth, and root phosphorus and carbohydrate content in Fraxinus pennsylvanica Marsh. New Phytol 103, 91-106

Duncan D (1955) Multiple range and multiple F-test. Biometrics 11, 1-42

Fernandez JA, Niell FX, Lucena J (1985) A rapid and sensitive automated determination of phosphate in natural waters. Limnol Oceanogr 30, 227-230

Giovannetti M, Mosse B (1980) An evaluation of techniques for measuring vesicular-arbuscular mycorrhizal infection in roots. New Phytol 84, 489-499

Guerra J, Alcaraz F, Egea JM, Hernandez J, Carrión JS, Martinez-Sanchez JJ, Sanchez P (1988) Densidad, Estructura Poblacional y Areas Potenciales para la Expansión de la Sabina Mora (Tetraclinis articulata) en el Litoral de la Región de Murcia. Arman, Murcia

Habte M, Aziz T (1985) Response of Sesbania grandiflora to inoculation of soil with vesicular-arbuscular mycorrhizal fungi. Appl Environ Microbiol 50, 701-703

Harley JL, Smith SE (1983) Mycorrhizal Symbiosis. Academic Press, London

Hayman DS (1983) The physiology of vesiculararbuscular endomycorrhizal symbiosis. Can $J$ Bot 61, 944-963

Hayman DS, Tavares M (1985) Plant growth responses to vesicular-arbuscular mycorrhiza. XV. Influence of soil $\mathrm{pH}$ on the symbiotic efficency of different endophytes. New Phytol 100, 367-377

Hetrick BAD, Wilson GT, Todd TC (1990) Differential responses of $\mathrm{C}_{3}$ and $\mathrm{C}_{4}$ grasses to mycorrhizal symbiosis, phosphorus fertilization, and soil microorganisms. Can J Bot 68, 461-467

Klopatek CC, Debano LF, Klopatek JM (1988) Effect of simulated fire on vesicular-arbuscular mycorrhizae in pinyon-juniper woodland soil. Plant Soil 109, 245-249

Koide RT, Li M (1990) On host regulation of the vesicular-arbuscular mycorrhizal big bluestem in nonsterile soil. New Phytol 109, 59-74

Kough JL, Molina R, Linderman RG (1985) Mycorrhizal responsiveness of Thuja, Calocedrus, Sequoia and Sequoiadendron species of western North America. Can J For Res 15, 1049-1054

Malloch D, Malloch B (1982) The mycorrhizal status of boreal plants: additional species from northeastern Ontario. Can J Bot 60, 1035-1040

Maronek DM, Hendrix JW, Kiernan J (1980) Differential growth response to the mycorrhizal fungus Glomus fasciculatus of southern magnolia and bar harbor juniper grown in containers in composted hardwood bark-shale. J Am Soc Hortic Sci 105, 206-208

Parke JL, Linderman RG, Trappe J (1983) Effects of forest litter on mycorrhiza development and growth 
of Douglas fir and western red cedar seedlings. Can J For Res 13, 666- 671

Phillips JM, Hayman DS (1970) Improved procedures for clearing roots and staining parasitic and vesicular-arbuscular mycorrhizal fungi for rapid assessment of infection. Trans Br Mycol Soc 55, 158-161

Sainz MJ, Arines J (1988) Effect of indigenous and introduced vesicular-arbuscular mycorrhizal fungi on growth and phosphorus uptake of Trifolium pratense and on inorganic phosphorus fractions in a cambisol. Biol Fertil Soils 6, 55-60

Smith SE, Gianinazzi-Pearson V (1988) Physiological interaction between symbionts in vesicular- arbuscular mycorrhizal plants. Ann Rev Plant Physiol Plant Mol Biol 39, 221-244

Sutton JC (1973) Development of vesiculararbuscular mycorrhizae in crop plants. Can $J$ Bot $51,2487-2493$

Thomson BD, Robson AD, Abbott LK (1986) Effects of phosphorus on the formation of mycorrhizas by Gigaspora calospora and Glomus fasciculatum in relation to carbohydrates. New Phytol 103, 751-765

Waterer DR, Coltman RR (1988) Phosphorus concentration and application interval influence growth and mycorrhizal infection of tomato and onion transplants. J Am Soc Hortic Sci 113, 704-708 